Dermatology 2000;200:151-152

\section{Transverse Nasal Line Associated with Congenital Persistent Milia}

Thomas Jansen ${ }^{\mathrm{a}}$, Ricardo Romiti ${ }^{\mathrm{b}}$, Peter Altmeyer

Departments of Dermatology and Allergology,

a Ruhr University of Bochum and b Ludwig Maximilian

University of Munich, Germany

\section{Key Words}

Nasal line $\cdot$ Milia

In 1951, a transverse nasal line was first described by Cornbleet [1] as a peculiar reddish streak in a group of 5 girls and was labeled stria nasi transversa. It is important to recognize the nasal line as a localizing factor for comedones [2] and milia [3, 4]. We describe the occurrence of congenital persistent milia associated with a transverse linear line in a child. The case is remarkable since the milia were not limited to the nasal line.

A 9-year-old white girl was referred to our department because of numerous, progressively appearing, asymptomatic small white cystic lesions located over the dorsum of the nose. The lesions had been present since birth but had become more obvious during the last 6 months. She was otherwise in good health and did not remember any local trauma to the nose.

Clinical examination revealed numerous whitish 1- to 2-mm papules on the nose. In addition, there was a line located between the middle and lower thirds of the nasal dorsum (fig. 1). This transverse nasal line had been present since birth and had persisted unchanged.

The sister and grandmother, aged 7 and 67 years, respectively, had a similar nasal line at the same location, but without milia. There was no history of either allergic or frequent episodes of rhinitis.

The milia were punctured with a needle and then expressed. They showed no recurrence after 2 years of follow-up.

The transverse nasal line is located at the upper border of the tip of the nose. The clinical spectrum varies from a faint transverse reddish line to a groove with a depth and width of up to several millimeters. In Afro-Caribbeans, a narrow thread-like band of hyperpigmentation may be seen. Females are mostly affected, although the nasal line may also rarely be found in males [5]. The transverse nasal line must be distinguished from the nasal crease or wrinkle described in patients with allergic rhinitis who rub their noses to relieve itching, the 'allergic salute' $[6,7]$.

Two cases of congenital persistent milia associated with a transverse nasal line have been reported so far [3, 4]. In both patients, cystic lesions were almost exclusively located along the nasal line, although in 1 patient a few similar lesions on the face were also noted [4].

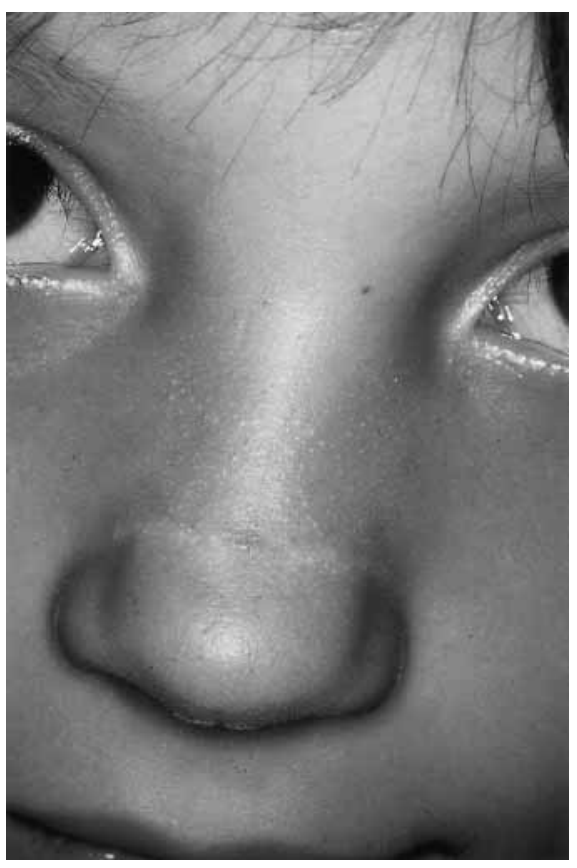

Fig. 1. Transverse nasal line and scattered milia on the dorsum of the nose.

In the original report of tranverse nasal line, Cornbleet [1] considered the transverse line as a result of differential growth of the nasal cartilages. He speculated that the nasal line develops at puberty, when the alar cartilages enlarged faster than the triangular cartilage of the nose. Anderson [8] described 14 cases from two families and suggested that the defect was caused by a single dominant gene which does not always find phenotypic expression. Recently, an embryological origin has been postulated by Shelley et al. [9]. This hypothesis states that the transverse line develops at the site of fusion of the frontal and medial nasal processes at 6 weeks of gestation. Normally, this fusion occurs without leaving any evidence.

Milia are common at all ages, but in infants they usually regress spontaneously in the third or fourth week of life. Persistence of milia or an unusually widespread distribution, particularly in association with other abnormalities, may be a manifestation of the type I oralfacial-digital syndrome or hereditary hypotrichosis (Marie Unna type hypotrichosis) [10]. However, no other defects were found in our patient.

\begin{tabular}{ll}
\hline KARGER & (c) 2000 S. Karger AG, Basel \\
Fax +4161306 1234 $34-8665 / 00 / 2002-0151 \$ 17.50 / 0$ \\
$\begin{array}{l}\text { E-Mail karger@karger.ch } \\
\text { www.karger.com }\end{array}$ & $\begin{array}{l}\text { Accessible online at: } \\
\text { www.karger.com/journals/drm }\end{array}$
\end{tabular}




\section{References}

1 Cornbleet T: Transverse nasal stripe at puberty (stria nasi transversa). Arch Dermatol 1951;63:70-72.

2 Piqué E, Olivares M, Fariña MC, Escalonilla P, Soriano ML, Martin L, Requena L: Congenital nasal comedones - Report of three cases. Clin Exp Dermatol 1996;21:220-221.

3 Del-Río E, Pena J, Aguilar A: Milia cysts along the nasal groove in a child. Clin Exp Dermatol 1993;18:289-290.

4 Akinduro OM, Burge SM: Congenital milia in the nasal groove (letter). Br J Dermatol 1994;130:800.

5 White SJ: Transverse nasal stripe. Arch Dermatol 1951;64:791.

6 Bowen R, Balyeat RM: Facial and dental deformities due to perennial nasal allergy in childhood. South Med J 1934;27:933-938.

7 Myers WA: The 'nasal crease': A physical sign of allergic rhinitis. JAMA 1960;174:1204-1206.

8 Anderson PC: Familial transverse nasal groove. Arch Dermatol 1961;84: 316-317.

9 Shelley WB, Shelley ED, Pansky B: The transverse nasal line: An embryonic fault line. Br J Dermatol 1997;137:963-965.

10 Hurwitz S: Clinical Pediatric Dermatology, ed 2. Philadelphia, Saunders, 1993, pp 12-13.

Dr. Thomas Jansen, Department of Dermatology and Allergology Ruhr University Bochum, Gudrunstrasse 56

D-44791 Bochum (Germany)

Tel. +49509 3411, Fax +495093409 